Boris Kossoy

Doutor em História, arquiteto, museólogo, fotógrafo e ensaísta. Professor Livre-Docente do Departamento de Jornalismo e Editoração da Escola de Comunicações e

Artes da USP.

\title{
CRIATIVIDADE E TECNOLOGIA NO MUNDO DA REPRESENTAÇÃO ${ }^{1}$
}

Fotografia: ficção documental, produzida a partir do ponto de vista do realizador

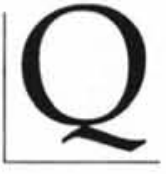

ualquer que seja o tema representado numa fotografia, ela traz a lembrança de uma época desaparecida, o aspecto simbólico sempre recorrente: a memória de um tempo sem volta.

A imagem fotográfica é antes de tudo uma representação a partir do real, segundo o olhar e a ideologia de seu autor. No entanto, em função da materialidade do registro, no qual se tem gravado o vestígio/aparência de algo que se passou na realidade concreta, em dado espaço e tempo, nós a tomamos, também, como um documento do real, uma fonte histórica.

O documento fotográfico não pode ser compreendido independentemente do processo e construção da representação em que se originou. A materialização da imagem ocorre enquanto etapa final e produto de um com- plexo processo de criação técnico, estético, cultural elaborado pelo fotógrafo. Temos na imagem fotográfica um documento criado, construído, razão por que a relação documento/representação é indissociável. A imagem fotográfica, seja ela analógica ou digital, é sempre um documento/representação.

A fotografia retrata o real na sua aparência e na sua ocorrência. Ela paralisa, no plano da imagem, uma realidade selecionada, um fragmento do real: nisso ela é documento. Trata-se de um documento, contudo, que resulta de um complexo processo de criação/construção elaborado cultural, técnica e esteticamente, portanto, ideologicamente, pelo seu autor; uma representação, pois, construída a partir do real: uma ficção documental.

Nessa linha pode-se perceber em que medida o registro ou o testemunho fotográfico

1. Síntese de texto baseado em artigo do autor publicado originalmente sob o título Ideologia da criação fotográfica. in: Revista da criação. São Paulo: Editora Meio \& Mensagem. Ano 6, n. 60, março 2000, p.52-53. Além do mencionado artigo o texto se fundamenta particularmente em dois livros: Fotografia e história e Realidades e ficções na trama fotográfica, obras que reúnem investigações teóricas desenvolvidas nos anos 80 e 90. 
obtido está definitivamente amalgamado ao processo de criação que the deu origem.

Trata-se da relação registro/criação ou testemunho/criação. Um binômio indivisível. É diante de tal ambigüidade fundamental que nos situamos quando analisamos as fontes fotográficas, tanto as produzidas no passado como as contemporâneas.

O chamado testemunho fotográfico, embora registre [documente] em seu conteúdo uma dada situação do real, sempre se constitui numa elaboração, no resultado final de um processo criativo, de um modo de ver e compreender especial, de uma visão de mundo particular do fotógrafo; é ele que, na sua intermediação, cria/ constrói a representação.

A fotografia é sempre ambígua, seja ela analógica ou digital, seja ela produto da realidade material ou virtual.

\section{A iconografia é um excelente instrumento para inventariar,} mostrar, evidenciar, denunciar mas, dependendo de seu uso político-ideológico, funciona também como ferramenta de propaganda.

O documento fotográfico se presta à denúncia social como também à publicidade; foi usado pela antropologia física do século XIX (no contexto dos preceitos positivistas), para documentar os seres primitivos das terras exóticas, como também no ateliê dos artistas-fotógrafos, para o registro desses mesmos seres posando na condição de constrangidos modelos diante de cenários europeus para coleções iconográficas que eram consumidas no berço da civilização.

A fotografia é resultante de um processo de criação/construção de realidades - e portanto de ficções - um processo ideológico inerente aos mecanismos mentais que regem a produção e recepção das imagens, isto é, de um lado, a produção da obra fotográfica por parte do fotógrafo (processo de construção da representação), de outro, sua recepção por parte dos diferentes receptores, suas diferentes leituras em precisos momentos da história (processo de construção interpretação). Este processo de criação/construção de realidades que se estriba em sua ambígua e definitiva condição de documento/representação nos levou a desenvolver a idéia de uma natureza ficcional que seria intrínseca à imagem fotográfica, base de todas as manipulações que desde sempre se fizeram dos fatos, seja nos palcos fotográficos do século XIX, seja na página impressa dos periódicos ao longo do século XX.

O chamado documento fotográfico não é inócuo. A imagem fotográfica não é um simples registro físico-químico ou eletrônico do assunto fotografado: qualquer que seja o objeto da documentação não se pode esquecer que a fotografia é sempre uma representação a partir do real intermediada pelo fotógrafo que a produz segundo sua forma particular de compreensão daquele real, seu repertório, sua ideologia. A imagem de qualquer objeto ou situação pode ser dramatizada ou estetizada de acordo com a ênfase (intenção) pretendida pelo fotógrafo-e/ou seus contratantes - em função da finalidade a que se destina. Nessa linha não é difícil imaginarmos que podemos criar/construir verdades dramatizadas e mentiras amenizadas tudo segundo os preceitos do mais "puro" realismo fotográfico. 
No caso das imagens fotográficas que serão veiculadas pelos meios de comunicação, o processo de construção da representação não se finaliza com a materialização da imagem através da criação do fotógrafo. Não é nenhuma novidade que a produção da representação, tal como é empreendida pelo fotógrafo, tem sequêencia ao longo da editoração da imagem. É o que poderíamos chamar de pós-produção, isto é, quando a imagem se vê objeto de uma série de adaptações visando à sua inserção na página do jornal, da revista, do cartaz etc.

Com a digitalização e os softwares especiais, as operações de falsificações das imagens fotográficas tornaram-se sedutoras, tais como retoques, aumento e diminuição de contrastes, eliminação ou introdução de elementos na cena, alteração de tonalidades, aplicação de texturas, enfim, uma higienização da imagem conforme os padrões impostos pela indústria cultural. Até as fotos de nus recebem cirurgias digitais localizadas para se tornarem mais eróticas.

Ampliam-se cada vez mais, através dos laboratórios de pós-produção digital, sofisticadas possibilidades tecnológicas de mon-

Resumo: $\mathrm{O}$ autor discute a fotografia e a linguagem fotográfica como signos da representação da realidade que, como tal, são expressões criativas dos pontos de vistas de seus produtores. Afirma que o documento fotográfico não pode ser compreendido independentemente de seu processo de produção. Com as novas tecnologias digitais, as potencialidades criativas do fotógrafo/criador aumentam, dando-lhe poderes de eliminação e introdução de elementos; a higienização da imagem adquire maiores potencialidades.

Palavras-chave: fotografia, documento, representação, tecnologias digitais, realidade tagens estéticas e ideológicas das imagens $\mathrm{e}$, por conseguinte, de criações de novas realidades: algumas jamais existiram. Porém a questão não é somente a da alteração ou manipulação da representação através das artimanhas da tecnologia digital. A questão maior reside na construção de fantasias tornadas realidades concretas uma vez que veiculadas pela mídia e consumidas enquanto produtos; ficções que sempre se fizeram independentemente das tecnologias. Qual é o futuro da História? Estamos mergulhados num sério problema de ordem ética. Alguém tem se mostrado preocupado com isso?

$\mathrm{O}$ futuro pode ser sombrio. Quando assistimos a uma crescente onda de substituição dos fatos pelas sua representações, quando as imagens da realidade vêm progressivamente assumindo uma existência autônoma, desprendidas de seus elementos constituintes em função dos avanços da tecnologia e do câmbio das ideologias, poderíamos falar de um contexto imaginário de informações artificiais e memórias sintéticas. É o mundo da representação que se insinua, tomando o lugar da representação do mundo.

(Creativity and technology in the world of representation)

Abstract. The author discusses photography and photographic language as signs of representation of reality which, as such, are creative expressions of the their producer's points of view. The claim is that the photographic document cannot be understood independently from its productive process. The photographer/creator's creative potential was increased by the new digital technologies and he/she now has the power to eliminate and introduce elements and, thus, the hygienization of the image reaches new potential.

Key words: photography, document, representation, digital technologies, reality 